\title{
Comparative lengths of digestive tracts of seven didelphid marsupials (Mammalia) in relation to diet
}

\author{
Nilton C. Cáceres \\ Departamento de Biologia, Universidade Federal de Santa Maria. Faixa de Camobi, km 9, 97105-900 Santa Maria, \\ Rio Grande do Sul, Brasil. E-mail: nc_caceres@hotmail.com
}

\begin{abstract}
The relative proportions of the digestive tract were rarely explored to understand the behaviour and the ecology of neotropical marsupials. In this study, proportions of the digestive tract and diet were compared in seven opossum species. The animals studied were Didelphis albiventris Lund, 1840, D. aurita WiedNeuwied, 1826, Metachirus nudicaudatus (Desmarest, 1817), Philander frenatus (Olfers, 1818), Lutreolina crassicaudata Desmarest, 1804, Monodelphis sorex (Hensel, 1872) and Caluromys lanatus (Olfers, 1818). Segments of digestive tracts of marsupials were measured and differences were statistically tested by Analysis of Variance and Covariance. Caecum and hard guts were responsible for the main differences among opossums, although all segments differed significantly. Caluromys lanatus was the most specialised species, with a large hard gut and caecum, small stomach and shorter small gut. The large caecum of $M$. nudicaudatus and the shortest hard gut of $M$. sorex were also noticed. The arboreal $C$. Ianatus has a well different feeding habit and life style regarding other marsupials studied, such as $M$. sorex and M. nudicaudatus which are terrestrial, corroborating the results reached.
\end{abstract}

KEY WORDS. Caecum, Caluromys lanatus, digestive tract proportions, hard gut, Metachirus nudicaudatus.

RESUMO. Dimensões comparadas de tratos digestivos de sete marsupiais didelfídeos (Mammalia) em relação à dieta. Proporções relativas do trato digestivo são raramente exploradas para entender o comportamento e a ecologia de marsupiais neotropicais. Neste estudo, proporções relativas do tubo digestivo e dieta de sete espécies de marsupiais são comparadas. Os animais estudados foram Didelphis albiventris Lund, 1840, D. aurita Wied-Neuwied, 1826, Metachirus nudicaudatus (Desmarest, 1817), Philander frenatus (Olfers, 1818), Lutreolina crassicaudata Desmarest, 1804, Monodelphis sorex (Hensel, 1872) e Caluromys lanatus (Olfers, 1818). Posteriormente, cada segmento do tubo digestivo destes marsupiais foi medido e as diferenças encontradas foram estatisticamente testadas usando a Análise de Variância e de Covariância. O ceco e o intestino grosso foram responsáveis pelas principais variações observadas, embora todos os segmentos alcançaram diferenças significantes. Caluromys lanatus foi a espécie mais especializada, apresentando grandes intestino grosso e ceco, pequeno estômago e intestino delgado mais curto. Destacou-se também o relativamente longo ceco de $M$. nudicaudatus e o intestino grosso mais curto de M. sorex. Caluromys lanatus, de hábito arborícola, apresenta alimentação e estilo de vida bem diferentes, considerando os outros marsupiais estudados, como $M$. sorex e $M$. nudicaudatus que são terrestres, confirmando os resultados alcançados.

PALAVRAS CHAVE. Ceco, proporções do trato digestivo, Caluromys lanatus, intestino grosso, Metachirus nudicaudatus.

Marsupials are a rich group of mammals in the neotropics with about 70 species. Among them, didelphids have the most wide distribution of species in the Neotropical region, many of them ranging from Mexico to Argentina. Didelphid marsupials occupy a variety of habitats, such as the tropical, submontane and montane forests, the arboreal, terrestrial and aquatic environment (Emmons \& Feer 1997) and present a continuum of feeding habits, from those species deeply omnivore to those more frugivore, insectivore or carnivore (LeITE et al. 1994, SANTORI et al. 1995a, Cáceres et al. 2002, Astúa de Moraes et al. 2003, CÁceres 2004, Santori et al. 2004, Vieira \& Astúa de Moraes 2004).

The digestive tract is important in the determination of the dietary type of marsupials (Crowe \& Hume 1997). In gen- eral, the form and size of its parts are functionally adapted. For example, carnivorous animals show larger stomachs and shorter guts whereas herbivorous-frugivorous animals often show smaller stomachs, long hard guts and developed caeca (Hildebrand 1995). Few studies have compared relative proportions of digestive tract or skulls (e.g. MedelLín 1991, SANTORI et al. 1995b, Sánchez-Villagra \& SMith 1997) to answer questions related to feeding habits of didelphid marsupials. One of them is how didelphids, having only slightly different diets, adjust structurally to these differences. This is the question that this paper intends to answer by comparing the relative proportions of digestive tracts of seven species of didelphid marsupials from southern Brazil.

Revista Brasileira de Zoologia 22 (1): 181-185, março 2005 


\section{MATERIAL AND METHODS}

The digestive tracts of seven species of didelphid marsupials ( $\mathrm{N}=29$ individuals, family Didelphidae) were obtained from adult individuals collected in the Paraná and Santa Catarina States. Species used were the white-eared opossum Didelphis albiventris Lund, 1840 (1500 g, N = 5 individuals), the southern black-eared opossum D. aurita Wied-Neuwied, 1826 (1200 g, N =4), the grey four-eyed opossum Philander frenata (Olfers, 1818) (250 g, N = 3), the brown four-eyed opossum Metachirus nudicaudatus (Desmarest, 1817) (290 g, N = 5), the short-tailed opossum Monodelphis sorex (Hensel, 1872) (45 g, $\mathrm{N}=6$ ), the woolly opossum Caluromys lanatus (Olfers, 1818) (300 g, $\mathrm{N}=3$ ) and the thick-tailed opossum Lutreolina crassicaudata (Desmarest, 1804) (600 g, $\mathrm{N}=3$ ). All animals used were deposited in the Capão da Imbuia Museum of Natural History (MHNCP) collection, in Curitiba, Brazil. Nomenclature follows FonseCA et al. (1996).

The complete digestive tract of fresh individuals, from pharynx to anus, was removed through a longitudinal section from the abdomen (beginning at the anus) to the throat. Latter, each digestive tract was extended on a salver with flat surface and the caecum, hard gut, small gut, stomach and oesophagus were measured with a $1 \mathrm{~mm}$ precision ruler. The length of each segment was measured after removing all mesenteric attachments but only when the tissue stopped contraction after its distension on the salver. For stomachs, after emptying all food material through a small incision, their areas were estimated by measuring their length on the longer stomach axis, and width on the shorter axis, perpendicularly.

The relative dimension of each portion of the digestive tract was obtained by dividing each measure (e.g. the caecum length) by the total length of the respective digestive tract. For comparison to other measures, the stomach area was transformed to its square root (MedelLín 1991).

The coefficient of variation of each segment of the digestive tract was calculated based on arithmetic means and standard deviation for each species ( $\mathrm{CV}=$ standard deviation / mean $x$ 100). Differences observed in digestive tracts of species were analysed statistically by two-way Analysis of Variance (ANOVA) and the Analysis of Covariance (ANCOVA), using the total digestive length as covariate, in order to increase the statistical power. Species that contributed more to differences in proportions of digestive tracts were tested by the post-hoc HSD Tukey test for samples of different sizes (ZAR 1984, StaTISTICA 1993). To avoid the variance heterogeneity associated with percentages (ZAR 1984), arcsin transformations were performed on relative proportions (CROWE \& Hume 1997).

\section{RESULTS}

The caecum was the segment of the digestive tract that varied more among species (average $\mathrm{CV}=36 \%$ ), followed by the hard gut (23\%). The longer segment in all species, the small gut, was the one that varied less (8\%). Stomach and oesophagus lengths varied at percentages of $16 \%$ and $20 \%$, respectively. However, the Covariance analysis, a more robust analysis, showed that hard gut $(\mathrm{F}=74.7 ;$ g.1. 6,$21 ; \mathrm{p}<0.0001)$ and small gut $(\mathrm{F}=70.3$; g.1. 6,$21 ; \mathrm{P}<0.0001)$ were the most important for general variations (see F values), although all segments differed significantly among species (for caecum: $\mathrm{F}=39.2$; g.l. 6, 21; $\mathrm{p}<0.0001$; for oesophagus: $\mathrm{F}=27.0$; g.l. 6,$21 ; \mathrm{p}<0.0001$, and for stomach: $\mathrm{F}=22.3$; g.1. 6, 21; $\mathrm{p}<0.0001$ ).

Using the Analysis of Variance, all relative measures of digestive tracts differed significantly between species but with a weaker $P$ value for the stomach (Tab. I). HSD Tukey test showed that $C$. lanatus differed from other species mainly because the small and hard intestines and caecum, M. nudicaudatus only because of the caecum (except in comparison with C. lanatus) and Monodelphis sorex because the hard intestine (Tab. I). Stomach, in general, did not differ between species. Thus, C. lanatus was the most different species, with a longer relative hard gut length (29\%), a large relative caecum (8\%), and short relative dimensions of the small intestine (51\%) and stomach (3.8\%) (Tab. II). Metachirus nudicaudatus had the longer relative caecum length (10\%) in relation to other species. In contrast to $C$. lanatus, M. sorex had the shortest relative hard gut length (13\%). Species of Didelphis were similar in all segments (Tabs I and II).

\section{DISCUSSION}

Caluromys lanatus and M. nudicaudatus were the species that have the larger variation observed in segments of digestive tracts, mainly regarding the caecum and hard guts. Despite of a long caecum, these two species have opposite life strategies, with C. lanatus having a strictly arboricolous habit and M. nudicaudatus being strictly terrestrial (Malcolm 1991, Cunha \& Vieira 2002). The great caecum and hard gut of $C$. lanatus may be related to a diet based on plant material, as occurs in other frugivorous-herbivorous mammals (CHIVERs \& Hadlik 1980, Charles-Dominique et al. 1981, for C. philander; Schieck \& Millar 1985). The genus Caluromys Allen, 1900 is relatively more specialized in the consumption of fruits, gums and twigs (Grand 1983, Leite et al. 1994, JuLien-Laferrière 1999), similarly to some primates (CHIVERS \& HADLIK 1980, PAssos 1999). A more frugivorous diet is associated to a small stomach chamber (Hildebrand 1995), just as observed here for C. lanatus.

A large hard gut may also function in the re-absorption of water from fruits (see Atramentowicz 1988), as is probably the case of species of Caluromys that live mostly in the forest canopy, rarely descending to the ground (MaLcolm 1991, Leite et al. 1994). Low levels of water deficit should occur seasonally even in tropical forests (such as the forested savannahs) during drier months (e.g. Smithe 1970), and C. lanatus, a species distributed in seasonal forests in central and southern Brazil (EMmons \& FeER 1997), could be benefited by exploring water from fruits, as suggested for the scansorial marsupial $D$. albiventris in the same region (SANTORI et al. 2004). 
Table I. Analysis of Variance (ANOVA) between relative measures of digestive tracts of seven didelphid marsupial species and post-hoc test of Tukey HSD showing the main genera that differed in the analyses.

\begin{tabular}{lcrll}
\hline \multicolumn{1}{c}{ Digestive tract } & $\mathrm{g} \mathrm{l}$ & $\mathrm{F}$ & $\mathrm{p}$ & \\
\hline Oesophagus & 6,24 & 12.2 & $<0.001$ & Lutreolina $\neq$ all species, except for Philander and M onodelphis \\
Stomach & 6,24 & 3.2 & $<0.050$ & NS \\
Small intestine & 6,24 & 21.6 & $<0.001$ & Caluromys $\neq$ all species \\
Caecum & 6,24 & 28.4 & $<0.001$ & Metachirus $\neq$ all species, except for Caluromys \\
Hard intestine & 6,24 & 47.6 & $<0.001$ & Caluromys and M onodelphis $\neq$ all species \\
\hline
\end{tabular}

Tukey test is significant at $p<0.05$ level. The symbol $\neq$ indicates the term "differed of". NS indicates no significant difference.

Table II. Distribution of total digestive tract lengths among segments (in \% for relative size; in cm for raw data) in seven species of didelphid marsupials from southern Brazil.

\begin{tabular}{lcccccc}
\hline Relative Size & $\mathrm{N}$ & Oesophagus & Stomach & Small intestine & Caecum & Hard intestine \\
\hline Caluromys lanatus & 3 & $7.9 \pm 1.1$ & $3.8 \pm 1.0$ & $51.0 \pm 1.7$ & $8.1 \pm 1.5$ & $29.2 \pm 0.9$ \\
Didelphis albiventris & 5 & $8.9 \pm 0.6$ & $5.1 \pm 0.5$ & $64.6 \pm 0.8$ & $4.4 \pm 0.5$ & $17.1 \pm 1.1$ \\
Didelphis aurita & 4 & $7.9 \pm 1.4$ & $4.3 \pm 0.8$ & $65.1 \pm 2.4$ & $4.2 \pm 0.5$ & $18.6 \pm 1.2$ \\
Lutreolina crassicaudata & 3 & $13.0 \pm 0.2$ & $5.4 \pm 1.2$ & $60.9 \pm 1.6$ & $3.0 \pm 0.1$ & $17.8 \pm 0.6$ \\
Metachirus nudicaudatus & 5 & $9.6 \pm 0.5$ & $5.5 \pm 1.0$ & $56.7 \pm 1.3$ & $10.3 \pm 0.8$ & $18.0 \pm 0.3$ \\
Monodelphis sorex & 6 & $10.7 \pm 1.4$ & $5.9 \pm 0.9$ & $64.5 \pm 1.9$ & $5.7 \pm 1.2$ & $13.3 \pm 1.0$ \\
Philander frenatus & 3 & $11.5 \pm 0.7$ & $5.4 \pm 0.8$ & $60.2 \pm 4.6$ & $5.3 \pm 1.2$ & $17.5 \pm 3.0$ \\
Raw Data & & & & & \\
Caluromys lanatus & 3 & $9.3 \pm 0.7$ & $4.5 \pm 1.3$ & $60.5 \pm 5.8$ & $9.5 \pm 1.3$ & $34.8 \pm 3.8$ \\
Didelphis albiventris & 5 & $15.8 \pm 1.6$ & $9.1 \pm 1.2$ & $114.9 \pm 8.0$ & $7.8 \pm 1.1$ & $30.4 \pm 3.4$ \\
Didelphis aurita & 4 & $14.2 \pm 1.7$ & $7.6 \pm 1.2$ & $117.7 \pm 10.4$ & $7.5 \pm 1.1$ & $33.6 \pm 2.5$ \\
Lutreolina crassicaudata & 3 & $11.8 \pm 2.8$ & $4.8 \pm 0.6$ & $55.6 \pm 14.0$ & $2.7 \pm 0.6$ & $16.1 \pm 3.3$ \\
Metachirus nudicaudatus & 5 & $8.5 \pm 1.2$ & $4.9 \pm 0.9$ & $50.6 \pm 7.0$ & $9.1 \pm 0.6$ & $16.0 \pm 1.9$ \\
Monodelphis sorex & 6 & $5.4 \pm 0.4$ & $3.0 \pm 0.5$ & $32.6 \pm 3.9$ & $2.9 \pm 0.8$ & $6.7 \pm 0.7$ \\
Philander frenatus & 3 & $9.8 \pm 1.0$ & $4.6 \pm 0.2$ & $51.5 \pm 8.4$ & $4.6 \pm 1.0$ & $15.0 \pm 3.0$ \\
\hline
\end{tabular}

$\mathrm{N}$ is the sample size. Means of species are given with standard deviation.

According to CHIVERS \& HADLIK (1980) and SCHIECK \& MILLAR (1985), hard gut size is one of the best indicators of diet in small mammals: the greater its dimension, the more herbivorous is the diet, and in contrast, the smaller the dimension, the more carnivorous (in a latu sensu, including all animal matter, sensu Vieira \& Astúa de Moraes 2003) is the diet. Accordingly, one could conclude that $M$. sorex is the more insectivore amongst the marsupials studied. Previously, CharLes-DominIQUe et al. (1981) reached this conclusion for M. brevicaudata (Erxleben, 1777) (Didelphidae) by analysing gut proportions and contents. On the other hand, CHIVERS \& HADLIK (1980) and SCHIECK \& Millar (1985) also pointed out that the small gut length does not help to elucidate the actual diet of an animal.

A large caecum is utilized in the storage and fermentation of food (plant material), or in the storage of vitamins (HILdEBRANd 1995). Hundreds of small seeds were seen concentrated into the caecum of an individual of $C$. Ianatus analysed (CÁCERES \& CASElLA in preparation) and this could be related, possibly, to storage of fruit components or vitamin extraction from them. Anyway, the diet of Caluromys is thought to be more herbivorous than previously known (JULIEN-LAFERRIËRE 1999, SANTORI et al. 2004), based on the proportion of its caecum (Crowe \& Hume 1997).

Despite the diet of $M$. nudicaudatus be more insectivore (SANTORI et al. 1995a, CÁCERES 2004), its caecum had a long relative dimension, though less complex (and smaller in volume; personal observation) than that of $C$. lanatus (SANTORI et al. 2004). This could be related to the absorption of water and electrolytes, as hypothesized for insectivorous mammals (ANDERson et al. 1992). Alternatively, it may be related to the metabolism of large volumes of chitin ingested, which would occur in the stomach and caecum of M. nudicaudatus hypothetically, through specific enzymes, as in other insectivorous mammals such as bats (WEBB et al. 1993). With such enzymes, bats may extract a reasonable quantity of carbohydrates from the chitinous skeleton of insects.

Revista Brasileira de Zoologia 22 (1): 181 185, março 2005 
The presence of a caecum in most didelphid marsupials is in agreement with the omnivory of the group (Astúa DE Moraes et al. 2003, SANTORI et al. 2004). Even the more carnivorousomnivorous marsupial Lutreolina crassicaudata has a relatively developed caecum when compared to other carnivorous marsupials (SANTORI et al. 2004, VIeIRA \& Astúa de Moraes 2004). Material plant such as fruits could be ingested since the first months of young opossums after their independence of the mother (CÁCEREs 2002, 2004). Furthermore, plant-eaters herbivorous or folivorous will have greater caeca for microbial fermentation than those frugivorous animals (Crowe \& Hume 1997), which will have larger caeca than more carnivorous marsupials.

The grey four-eyed opossum, $P$. frenatus, differently of the expected based on its more carnivorous diet (SANTORI et al. 1995b, 1997, 2004, CÁCERES 2004), did not show significant differences in the stomach chamber size among other opossum species. According to Hildbrand (1995), specialized carnivorous animals tend to have big and elastic stomachs to eat and temporarily store large quantities of meat in each meal. Philander frenatus appears to be a omnivorous mammal not well adapted to the function of carnivory but with trends to this (SANTORI et al. 2004). Tests of laboratory food preferences indicated the same trend for this species (Astúa de Moraes et al. 2003).

Dimensions of digestive tracts of didelphid marsupials may hide phylogenetic characteristics that mask functional adaptations, becoming difficult to detect them. For example, the neotropical kinkajou Potos flavus (Schreber, 1774) (Procyonidae) (Charles-Dominique et al. 1981, Julien-Laferrière 1993) and the African hyena Proteles cristatus (Spaarman, 1783) (Hyenidae) (ANDERSON et al. 1992) exhibit digestive tracts of carnivores (resembling their ancestral) but today their diets are frugivorous and insectivorous, respectively. Also, the gastrointestinal morphology of Pseudocheiridae Australian marsupials is conditioned by phylogeny rather than diet or habitat (CROWE \& Hume 1997). Phylogeny may have constrained the form of digestive tract of didelphid marsupials, yet differences between species with opposite life strategies suggest that there was space for adaptations in the group. Taxa such as Caluromys and Monodelphis appear to differ much more in form, differences that are in agreement with their opposite diets.

\section{ACKNOWLEDGMENTS}

Thanks to M. Miretzki, T.C.C. Margarido and Tião for administrative and technical assistance, respectively, in the Capão da Imbuia Museum of Natural History (MHNCP), S.A. Morato from COPEL and M.E. Graipel from UFSC for providing me specimens, E.L.A. Monteiro-Filho, H.G. Bergallo and M.V. Vieira for helpful advices on the early drafts of the manuscript, and the "Curso de Pós-Graduação em Zoologia" at the Universidade Federal do Paraná and CAPES/MEC/Brazil for support and grants, respectively. Special thanks to two anonymous referees that contributed to the final version of the manuscript.

\section{REFERENCES}

Anderson, M.D.; P.R.K. Richardson \& P.F. Woodall. 1992. Functional analysis of the feeding apparatus and digestive tract anatomy of the aardwolf Proteles cristatus. Journal of Zoology, Cambridge, 228: 423-434.

Astúa de Moraes, D.; R.T. Santori; C.E.V. Grelle \& R. Cerqueira. 2003. Nutritional and fibre contents of laboratory established diets of neotropical opossums, p. 229-237. In: M. JoNEs, C. Dickman \& M. Archers (Eds). Predators with pouches: the biology of carnivorous marsupials. Collingwood, CSIRO Publishing, XIV+486p.

Atramentowicz, M. 1988. La frugivorie opportuniste de trois marsupiaux didelphidés de Guyane. Revue d'Ecologie Terre et Vie, Paris, 43: 47-57.

CÁceres, N.C. 2002. Food habits and seed dispersal by the whiteeared opossum, Didelphis albiventris, in southern Brazil. Studies on Neotropical Fauna \& Environment, Lisse, 37: 97-104.

Cáceres, N.C. 2004. Diet of three marsupials (Mammalia, Didelphimorphia) in southern Brazil. Mammalian Biology, Jena, 69: 430-433.

Cáceres, N.C.; I.R. Ghizoni-Jr. \& M.E. Graipel. 2002. Diet of two marsupials, Lutreolina crassicaudata and Micoureus demerarae in a coastal Atlantic Forest island of Brazil. Mammalia, Paris, 66: 331-340.

Charles-Dominique, P.; M. Atramentowicz; M. Charles-Dominique; H. Gérard; A. Hladik; C.M. Hladik \& M.F. Prévost. 1981. Les mammiferes frugivores arboricoles nocturnes d'une forest guyanaise: interrelations plantes-animaux. Revue d'Ecologie Terre et Vie, Paris, 35: 341-435.

Chivers, D.J. \& C.M. HLadik. 1980. Morphology of the gastrointestinal tract in primates: comparisons with other mammals in relation to diet. Journal of Morphology, 166, 337386.

Crowe, O. \& I.D. Hume. 1997. Morphology and function of the gastrointestinal tract of Australian folivorous possums. Australian Journal of Zoology, Collingwood, 45: 357-368.

Cunha, A.A. \& M.V. Vieira. 2002. Support diameter, incline, and vertical movements of four didelphid marsupials in the Atlantic forest of Brazil. Journal of Zoology, Cambridge, 258: 419-426.

EMmons, L.H. \& F. FeER. 1997. Neotropical rainforest mammals: a field guide. Chicago, University of Chicago Press, $\mathrm{XVI}+307 \mathrm{p}$.

Fonseca, G.A.B.; G. Herrmann; Y.R.L. Leite; R.A. Mittermeier; A.B. Rylands \& J.L. Patton. 1996. Lista anotada dos mamíferos do Brasil. Occasional Papers in Conservation Biology, Belo Horizonte, 4: 1-38.

Grand, T.I. 1983. Body weight: its relationship to tissue composition, segmental distribution of mass, and motor function. III. The didelphid of French Guyana. Australian Journal of Zoology, Collingwood, 31: 299-312. 
Hildebrand, M. 1995. Análise da estrutura dos vertebrados. São Paulo, Atheneu, XX+700p.

JULIEN-LAFERRIÈRE, D. 1993. Radio-tracking observation on ranging and foraging patterns by kinkajous (Potos flavus) in French Guiana. Journal of Tropical Ecology, Cambridge, 9: 19-32.

JuLIEN-LAFERrière, D. 1999. Foranging strategies and food partitioning in the neotropical frugivorous mammals Caluromys philander and Potos flavus. Journal of Zoology, Cambridge, 247: 71-80.

Leite, Y.L.R.; J.R. Staluings \& L.P. Costa. 1994. Partição de recursos entre espécies simpátricas de marsupiais na Reserva Biológica de Poço das Antas, Rio de Janeiro. Revista Brasileira de Biologia, Rio de Janeiro, 54: 525-536.

Malcolm, J.R. 1991. Comparative abundances of neotropical small mammals by trap height. Journal of Mammalogy, Provo, 72: 188-192.

Medellín, R.A. 1991. Ecomorfología del cráneo de cinco didelfidos: tendencias, divergencias e implicaciones. Anales del Instituto de Biología de la Universidad Nacional Autónoma de México, Serie Zoología, México, 62: 269-286.

Passos, F.C. 1999. Dieta de um grupo de mico-leão-preto, Leontopithecus chrysopygus (Mikan) (Mammalia, Callitrichidae), na Estação Ecológica dos Caetetus, São Paulo. Revista Brasileira de Zoologia, Curitiba, 16: 269-278.

SÁnchez-Villagra, M.R. \& K.K. Smith. 1997. Diversity and evolution of the marsupial mandibular angular process. Journal of Mammalian Evolution, Heidelberg, 4: 119-144.

Santori, R.T.; D. Astúa de Moraes \& R. Cerqueira. 1995a. Diet composition of Metachirus nudicaudatus and Didelphis aurita (Marsupialia, Didelphoidea) in Southeastern Brazil. Mammalia, Paris, 59: 511-516.
Santori, R.T.; R. Cerqueira \& C.C. Kleske. 1995b. Anatomia e eficiência digestiva de Philander opossum e Didelphis aurita (Didelphimorphia, Didelphidae) em relação ao hábito alimentar. Revista Brasileira de Biologia, Rio de Janeiro, 55: 323-329.

Santori, R.T.; D. Astúa de Moraes; C.E.V. Grelle \& R. Cergueira. 1997. Natural diet at a restinga forest and laboratory food preferences of the opossum Philander frenata in Brazil. Studies on Neotropical Fauna and Environment, Lisse, 32: 12-16.

Santori, R.T.; D. Astúa de Moraes \& R. Cerqueira. 2004. Comparative gross morphology of the digestive tract in ten Didelphidae marsupial species. Mammalia, Paris, 68: 27-36.

Schieck, J.O. \& J.S. Millar. 1985. Alimentary tract measurements as indicators of diets of small mammals. Mammalia, Paris, 49: 93-104.

Smithe, N. 1970. Relationships between fruiting seasons and seed dispersal methods in a neotropical forest. American Naturalist, Chicago, 104: 25-35.

Statistica For Windows. 1993. Release 4.2 (A). USA, StatSoft.

Vieira, E.M. \& D. Astúa De Moraes. 2003. Carnivory and insectivory in neotropical marsupials, p. 271-284. In: M. Jones; C. Dickman \& M. Archers (Eds). Predators with pouches: the biology of carnivorous marsupials. Collingwood, CSIRO Publishing, XIV+486p.

Webb, P.I.; J.R. Speakman \& P.A. Racey. 1993. Defecation, apparent absorption efficiency, and the importance of water balance in captive brown long-eared (Plecotus auritus) and Daubenton's (Myotis daubentoni) bats. Journal of Zoology, London, Cambridge, 230: 619-628.

ZAR, J.H. 1984. Biostatistical analisys. Englewood Cliffs, Prentice-Hall, XIV+718p.

Received in 27.IV.2004; accepted in 11.II.2005. 